\title{
Aplikasi Sistem Pakar Pendeteksi Penyakit Tuberkulosis Berbasis Android
}

\author{
Eko Didik Widianto*, Yuni Waz Zaituun, Ike Pertiwi Windasari \\ Departemen Teknik Sistem Komputer, Fakultas Teknik, Universitas Diponegoro \\ Jl. Prof. Soedarto, SH, Kampus Undip Tembalang, Semarang, Indonesia 50275 \\ *didik@live.undip.ac.id
}

\begin{abstract}
Abstrak-Penelitian ini mengembangkan aplikasi sistem pakar secara khusus untuk mendeteksi dini penyakit tuberkulosis paru, tuberkulosis tulang dan tuberkulosis kelenjar. Aplikasi dikembangkan untuk berjalan di perangkat Android. Proses diagnosis menggunakan metode forward chaining dari 18 gejala ketiga penyakit tersebut, baik gejala wajib maupun gejala tidak wajib. Basis data menggunakan SQLite. Untuk menghitung jumlah gejala yang dipilih oleh pengguna terhadap jumlah gejala penyakit tersebut, digunakan probabilitas klasik. Secara fungsional, sistem pakar telah dapat berjalan di perangkat Android untuk mendeteksi dini penyakit tuberkulosis paru, tulang dan kelenjar serta telah divalidasi hasil deteksinya oleh pakar secara langsung.
\end{abstract}

Kata Kunci: tuberkulosis, sistem pakar, aplikasi Android, forward chaining, teori probabilitas klasik

\section{Pendahuluan}

Tuberkulosis (TBC) merupakan penyakit menular yang umum dan dalam beberapa kasus bersifat mematikan. Penyakit ini disebabkan oleh berbagai strain mikobakteria, umumnya mycobacterium tuberculosis (disingkat "MTb" atau "MTbc"). Tuberkulosis biasanya menyerang paru-paru, namun juga bisa berdampak pada bagian tubuh lainnya. Tuberkulosis menyebar melalui udara ketika seseorang dengan infeksi tuberkulosis aktif batuk, bersin atau menyebarkan butiran ludah mereka melalui udara [1].

World Health Organization (WHO) menyatakan bahwa penyakit tuberkulosis paru saat ini telah menjadi ancaman global karena hampir sepertiga penduduk dunia telah terinfeksi [2]. Sebanyak 95\% kasus tuberkulosis dan $98 \%$ kematian akibat tuberkulosis di dunia, terjadi pada negara-negara berkembang. Tuberkulosis merupakan penyebab kematian nomor satu di antara penyakit menular dan merupakan peringkat ketiga dari 10 penyakit pembunuh tertinggi di Indonesia yang menyebabkan 100.000 kematian setiap tahunnya [3]. Meningkatnya jumlah penderita tuberkulosis dipengaruhi oleh banyaknya rakyat miskin dengan pola hidup yang tidak sehat, lingkungan yang tidak bersih dan kurangnya informasi tentang penyakit tersebut beserta gejala dan penyebabnya yang akan membuat proses penanganan menjadi lambat. Proses penanganan yang lambat dan tidak tepat akan membuat penyakit semakin parah dan berakibat fatal.

Saat ini teknologi telah banyak dimanfaatkan dalam bidang medis. Salah satunya adalah sistem pakar. Sistem pakar adalah program yang dirancang untuk menirukan keahlian seorang pakar dalam menjawab pertanyaan dan menyelesaikan suatu permasalahan pada berbagai bidang. Dengan sistem pakar, orang awam dapat menyelesaikan masalah dengan informasi yang akurat yang sebenarnya hanya dapat diselesaikan oleh ahli atau pakarnya, seperti untuk deteksi dini meningitis dan gastroenteritis serta penentuan kebutuhan gizi individu dalam [4]-[6].

Pengembangan sistem pakar untuk deteksi dini tuberkulosis juga telah banyak dilakukan [7]-[11]. Platform aplikasi beragam, yaitu berbasis web [7]-[8] menggunakan PHP-MySQL dan desktop [9]-[11] menggunakan Delphi dan Visual Basic. Aplikasi dapat mendeteksi secara khusus penyakit tuberkulosis [8]-[10] dan tuberkulosis ditambah penyakit lain [7], [11]. Algoritma sistem pakar yang digunakan adalah antara lain forward chaining seperti dalam [9] dan [11], certainty factor (CF) dalam [7], [10], dan fuzzy Sugeno dalam [9].

Penelitian ini bertujuan untuk mengembangkan aplikasi sistem pakar untuk deteksi dini penyakit tuberkulosis menggunakan metode forward chaining seperti dalam [9], [11]. Berbeda dengan Arsyad [9] serta Mulyani dan Restianie [11] yang mengembangkannya berbasis desktop, aplikasi ini dikembangkan untuk dijalankan di perangkat berbasis Android seperti dalam [4]-[5] yang menggunakannya untuk mendeteksi dini meningitis dan gastroenteritis. Secara khusus, penyakit TBC yang hendak dideteksi oleh aplikasi yang dikembangkan dalam penelitian ini adalah tuberkulosis paru, tuberkulosis tulang, dan tuberkulosis kelenjar.

\section{Metode}

Tahapan pengembangan aplikasi deteksi dini tuberkulosis ini adalah meliputi koleksi pengetahuan, perancangan sistem, dan pengujian. Lingkup jenis penyakit yang dideteksi adalah tuberkulosis paru, tuberkulosis tulang, dan tuberkulosis kelenjar. 


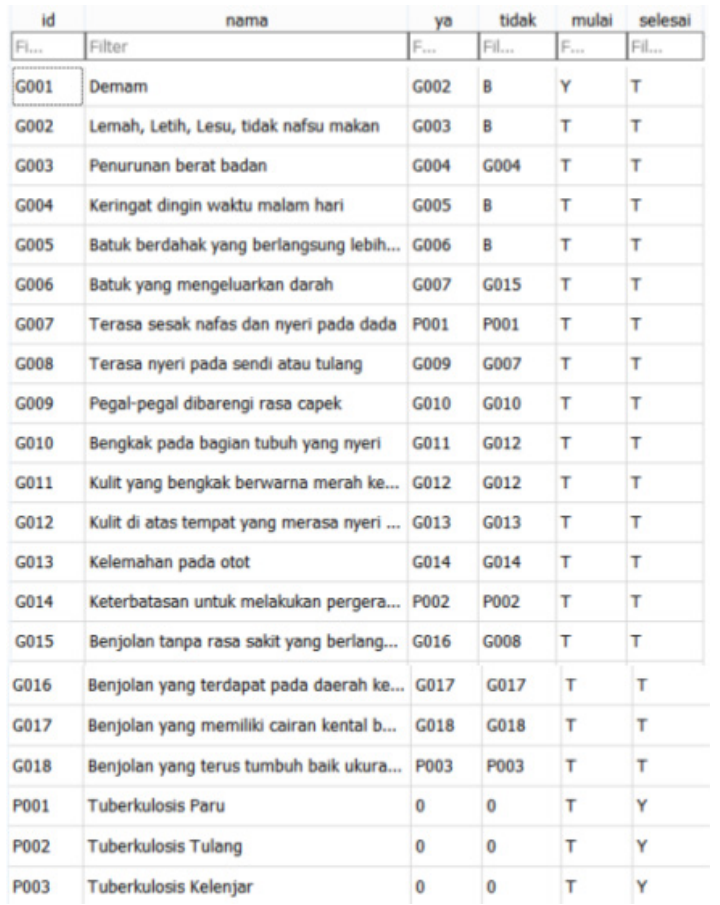

Gambar 1. Struktur Tabel Gejala

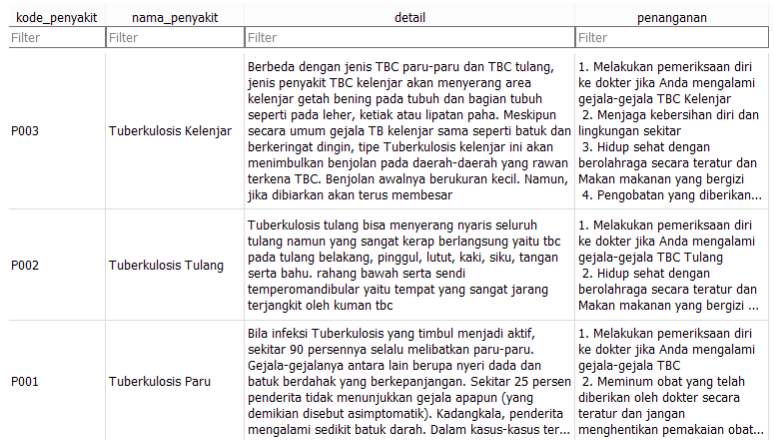

Gambar 2. Struktur Tabel Penyakit

Tabel 1. Kode Gejala dan Penyakit

\begin{tabular}{ll}
\hline Kode & \multicolumn{1}{c}{ Nama Gejala dan Penyakit } \\
\hline G001 & Demam \\
G002 & Lemah, letih, lesu, tidak nafsu makan \\
G003 & Penurunan berat badan \\
G004 & Keringat dingin waktu malam hari \\
G005 & Batuk berdahak yang berlangsung lebih dari 14 hari \\
G006 & Batuk yang mengeluarkan darah \\
G007 & Terasa sesak nafas dan nyeri dada \\
G008 & Terasa nyeri pada sendi atau tulang \\
G009 & Pegal-pegal dibarengi rasa capek \\
G010 & Bengkak pada bagian tubuh yang nyeri \\
G011 & Kulit yang bengkak berwarna merah kebiruan \\
G012 & Kulit di atas tempat yang merasa nyeri terkadang terasa panas dan terkadang terasa dingin \\
G013 & Kelemahan pada otot \\
G014 & Keterbatasan untuk melakukan pergerakan \\
G015 & Benjolan tanpa rasa sakit yang berlangsung lama \\
G016 & Benjolan yang terdapat pada daerah kelenjar getah bening, misal di leher atau ketiak \\
G017 & Benjolan yang memiliki cairan kental berupa nanah \\
G018 & Benjolan yang terus tumbuh baik ukuran maupun jumlahnya \\
P001 & Tuberkulosis Paru \\
P002 & Tuberkulosis Tulang \\
P003 & Tuberkulosis Kelenjar
\end{tabular}


Tabel 2. Tabel keputusan sistem pakar

\begin{tabular}{cccc}
\hline Kode & \multicolumn{3}{c}{ Kode Penyakit } \\
\cline { 2 - 4 } Gejala & P001 & P002 & P003 \\
\hline G001 & $*$ & $*$ & $*$ \\
G002 & $*$ & $*$ & $*$ \\
G003 & v & v & v \\
G004 & $*$ & $*$ & $*$ \\
G005 & $*$ & $*$ & $*$ \\
G006 & v & & \\
G007 & v & & \\
G008 & & $*$ & \\
G009 & & v & \\
G010 & & v & \\
G011 & & v \\
G012 & & v & \\
G013 & & & \\
G014 & & & \\
G015 & & & \\
G016 & & & \\
G017 & & & \\
G018 & & & \\
\hline
\end{tabular}

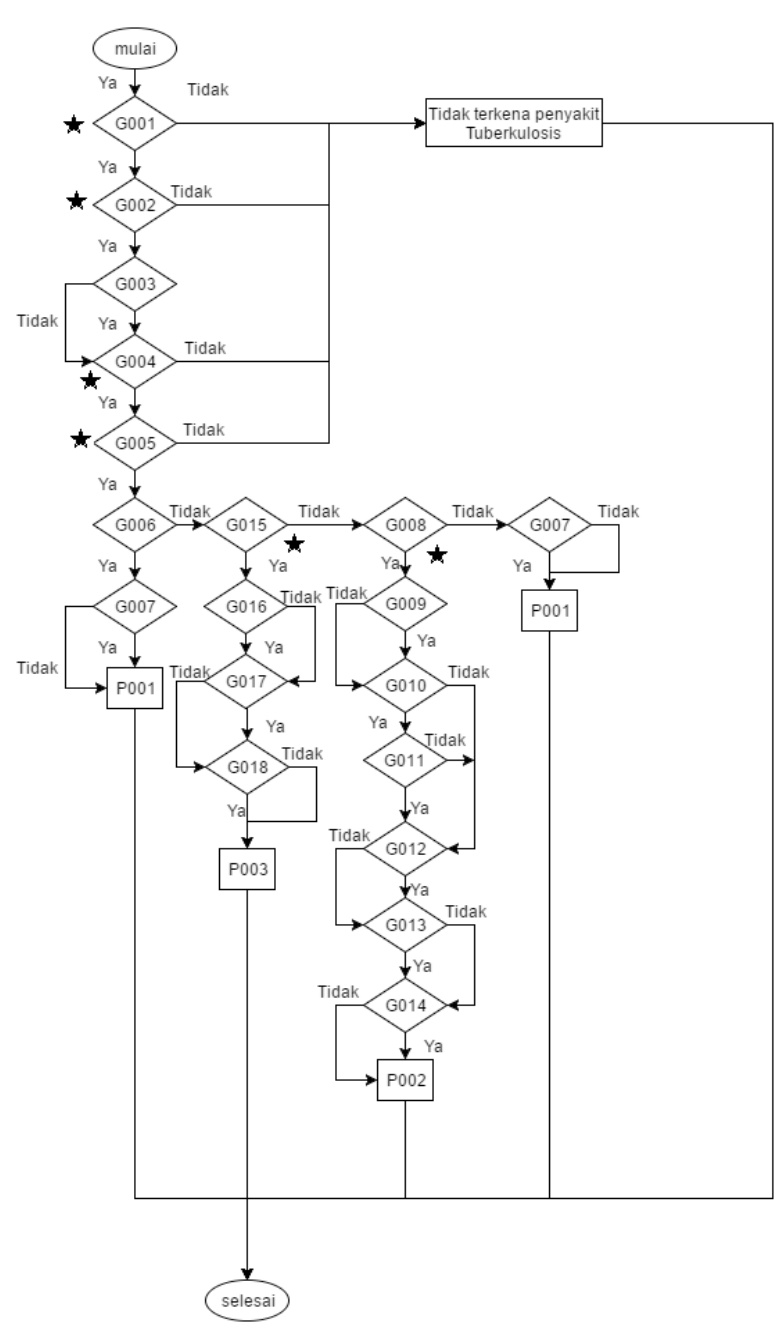

Gambar 3. Diagram alir program 
Tahapkoleksipengetahuan dilakukan dengan menggali pengetahuan dari pakar tentang penyakit tuberkulosis, jenis, dan gejalanya. Pengetahuan ini digunakan sebagai basis pengetahuan pakar untuk aturan produksi sistem dalam tahap perancangan dan implementasi sistem pakar. Tahap ini merancang desain tampilan dan antarmuka sistem, desain basis data sistem, serta cara kerja sistem. Hasil dari perancangan diimplementasikan ke dalam aplikasi sistem pakar. Aplikasi ini dibuat dengan software Android Studio dan basis data SQLite. Tahap pengujian sistem pakar dilakukan untuk mengevaluasi sistem secara fungsional.

Pembuatan basis data dilakukan dengan menggunakan basis data SQLite yang diprogram langsung dari kelas basis data. Dalam tahap ini terdapat dua buah query untuk membentuk dua buah tabel, yaitu tabel gejala dan tabel penyakit.

Tabel gejala berisi kolom id, nama, ya, tidak, mulai, dan selesai dengan id sebagai primary key yang ditunjukkan dalam Gambar 1. Kolom id berisi isian dengan kode gejala yang unik. Kolom nama berisi nama-nama gejala dari suatu penyakit. Kolom ya berisi id gejala dan penyakit di mana saat pengguna memilih jawaban ya. Kolom tidak berisi id gejala dan penyakit yang jika pengguna memilih jawaban tidak. Kolom mulai dan selesai berisi teks Y dan T, di mana jika pertanyaan pertama dimulai dan pertanyaan yang menyatakan telah selesai akan berisi Y. Terdapat 18 jumlah gejala yang dibutuhkan untuk mendefinisikan gejala-gejala dari tiap penyakit.

Tabel penyakit berisi kolom kode_penyakit sebagai primary key, nama_penyakit, detail, dan penanganan yang ditunjukkan dalam Gambar 2. Kolom kode diberi format isian $\mathrm{P} 00+$ nomor urutan penyakit. Kolom nama_penyakit berisi nama dari masing-masing penyakit. Pada sistem pakar pendeteksi penyakit tuberkulosis ini, data penyakit hanya terdiri dari 3 jenis penyakit tuberkulosis yaitu tuberkulosis paru, tuberkulosis tulang, dan tuberkulosis kelenjar. Kolom detail berisi deskripsi dari masing-masing penyakit sedangkan kolom penanganan berisi upaya pencegahan dan penanganan dari tiap penyakit.

Dalam sistem pakar ini, penelusuran hasil deteksi menggunakan penelusuran runut maju. Alur penelusuran maju ditunjukkan oleh Gambar 3. Pada diagram alir ini disebutkan kode-kode gejala dan penyakit. Daftar kode gejala dan penyakit dinyatakan pada Tabel 1 .

Proses deteksi pada masing-masing penyakit memiliki gejala yang wajib dipilih dan gejala yang tidak wajib dipilih. Pada diagram alir Gambar 3 terdapat tanda bintang yang menandakan gejala wajib dipilih. Gejala yang wajib dipilih adalah G001, G002, G004, dan G005. Jika salah satu dari gejala yang wajib dipilih tidak terpenuhi, maka sistem akan menyatakan bahwa penyakit yang diderita bukan termasuk penyakit tuberkulosis. Penyakit tuberkulosis tulang (P002) memiliki gejala khusus yaitu G008. Jika pengguna memilih gejala G008, maka akan mengarah ke gejala selanjutnya yang dimiliki oleh penyakit tuberkulosis tulang dan hasilnya akan dihitung nilai probabilitasnya. Penyakit tuberkulosis kelenjar (P003) juga memiliki gejala khusus yaitu G015. Jika pengguna memilih gejala G015, maka akan mengarah ke gejala selanjutnya yang dimiliki oleh penyakit tuberkulosis kelenjar dan akan dihitung nilai probabilitasnya. Jika kedua gejala khusus tersebut tidak dipilih pengguna maka gejala selanjutnya akan mengarah ke gejala yang dimiliki penyakit tuberkulosis paru.

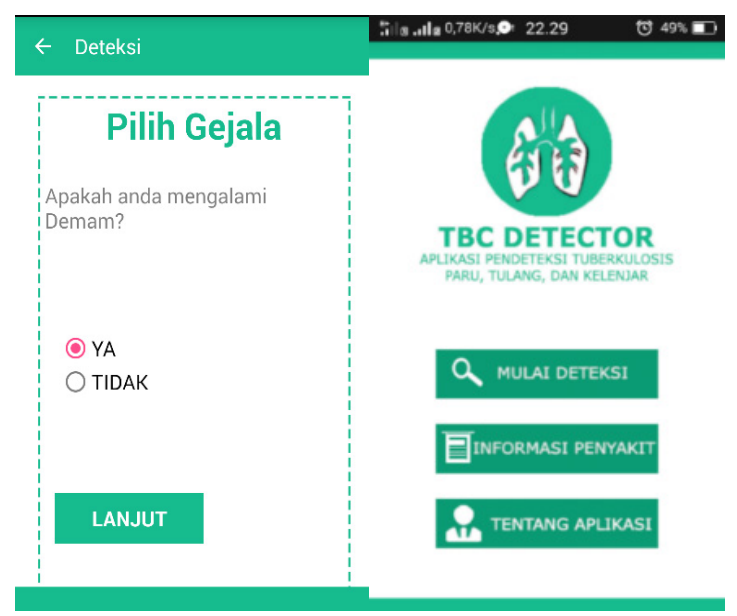

Gambar 4. Halaman Utama dan Deteksi Aplikasi

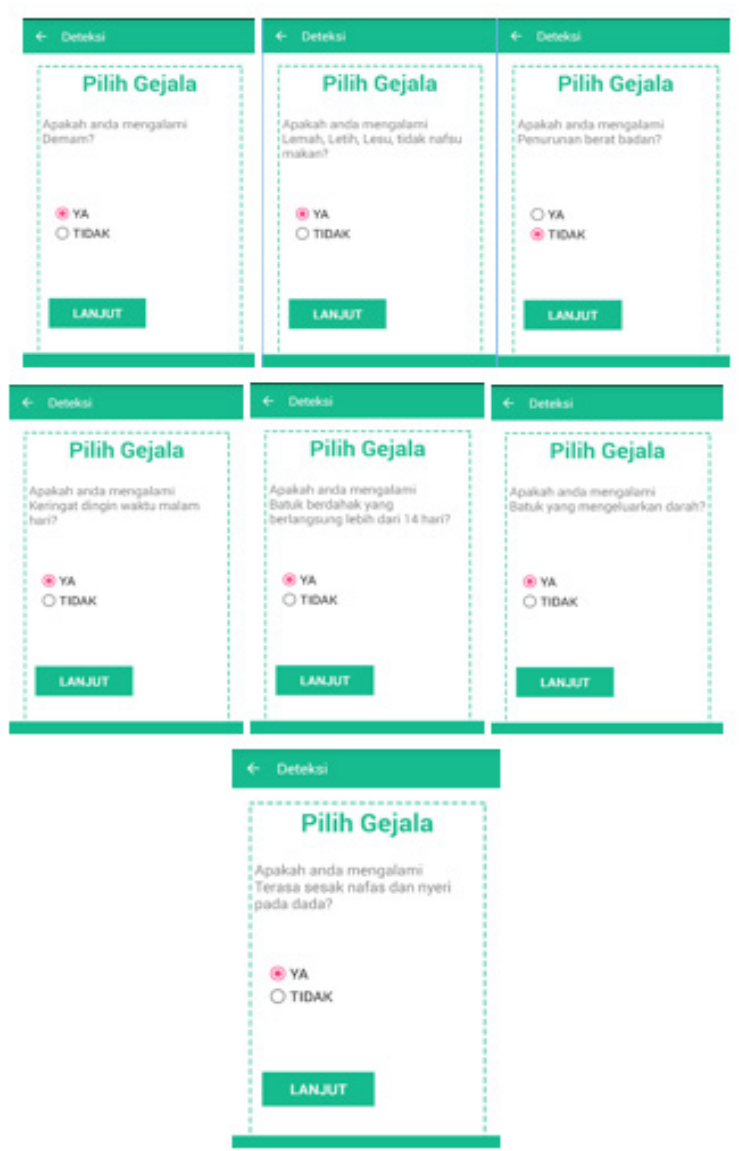

Gambar 5. Pertanyaan Gejala (Kasus)

Gejala yang dipilih memiliki aturan produksi yang diperoleh dari tabel keputusan. Keputusan tersebut berdasarkan dari gejala umum ke gejala khusus. Gejala yang sudah diberikan diklasifikasikan per penyakit yang mempunyai gejala yang sama. Hasil pengujian didapatkan dari tabel keputusan seperti dinyatakan pada Tabel 2. Tanda $*$ menunjukkan gejala yang wajib dipilih, sedangkan tanda $\mathrm{v}$ menunjukkan gejala yang tidak wajib dipilih.

Teori probabilitas klasik digunakan dalam aplikasi untuk menunjukkan persentase gejala penyakit yang dipilih oleh pengguna dengan total gejala penyakit. Persentase tersebut dinyatakan dalam $\mathrm{P}(\mathrm{E})$ sesuai Persamaan 1 . Parameter a menyatakan gejala yang dipilih, sedangkan b menyatakan jumlah total gejala penyakit tersebut sesuai 
$\leftarrow$ Hasil Deteksi

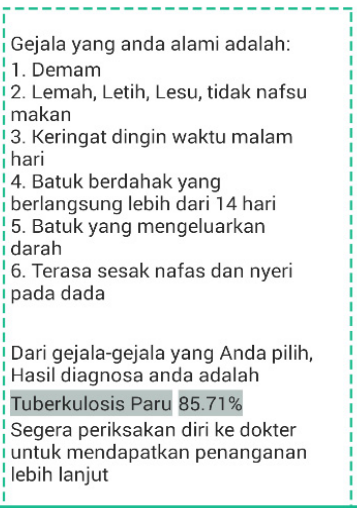

Gambar 6. Hasil Deteksi Penyakit

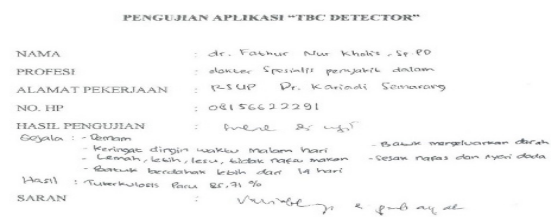

Gambar 7. Hasil Pengujian Pakar

Tabel 3. Pengujian Fungsi Halaman Hasil Deteksi

\begin{tabular}{|c|c|c|c|}
\hline $\begin{array}{c}\text { Nama } \\
\text { Pengujian }\end{array}$ & $\begin{array}{c}\text { Bentuk } \\
\text { Pengujian }\end{array}$ & Hasil yang Diharapkan & $\begin{array}{c}\text { Hasil } \\
\text { Pengujian }\end{array}$ \\
\hline $\begin{array}{l}\text { Menguji hasil } \\
\text { deteksi }\end{array}$ & $\begin{array}{l}\text { Memilih gejala- } \\
\text { gejala yang } \\
\text { dialami }\end{array}$ & $\begin{array}{l}\text { Tampil gejala-gejala yang dipilih, hasil diagnosis, dan } \\
\text { persentase kemungkinan penyakit }\end{array}$ & Berhasil \\
\hline $\begin{array}{l}\text { Menguji fungsi } \\
\text { menu "Back" }\end{array}$ & $\begin{array}{l}\text { Tekan tombol } \\
\text { menu "Back" }\end{array}$ & Tampil halaman Awal sistem pakar & Berhasil \\
\hline
\end{tabular}

Tabel 4. Rencana pengujian fungsional sistem pakar

\begin{tabular}{lll}
\hline \multicolumn{1}{c}{ Item Pengujian } & \multicolumn{1}{c}{ Detail Pengujian } & $\begin{array}{c}\text { Jenis } \\
\text { Pengujian }\end{array}$ \\
\hline & Pengujian fungsi "Mulai Deteksi" & Black Box \\
Fungsi Halaman Utama & Pengujian fungsi "Informasi Penyakit" & Black Box \\
& Pengujian fungsi "Tentang Aplikasi" & Black Box \\
& Pengujian masukan "Ya" & Black Box \\
Fungsi Halaman Mulai & Pengujian masukan "Tidak" & Black Box \\
Deteksi & Pengujian masukan "Lanjut" & Black Box \\
& Pengujian masukan "Back" & Black Box \\
Halaman Hasil Deteksi & Pengujian hasil deteksi penyakit & Black Box \\
& Pengujian fungsi "Back" & Black Box \\
Halaman Informasi & Pengujian fungsi informasi penyakit & Black Box \\
Penyakit & Pengujian fungsi "Back" & Black Box \\
\hline
\end{tabular}


Tabel 5. Pengujian fungsi halaman informasi penyakit

\begin{tabular}{|c|c|c|c|c|}
\hline $\begin{array}{c}\text { Nama } \\
\text { Pengujian }\end{array}$ & $\begin{array}{c}\text { Bentuk } \\
\text { Pengujian }\end{array}$ & \multicolumn{2}{|r|}{ Hasil yang Diharapkan } & $\begin{array}{r}\text { Ha } \\
\text { Pengu }\end{array}$ \\
\hline $\begin{array}{l}\text { Menguji fungsi halaman } \\
\text { informasi penyakit }\end{array}$ & $\begin{array}{l}\text { Klik tombol "tab view" } \\
\text { pada nama penyakit }\end{array}$ & \multicolumn{3}{|c|}{$\begin{array}{l}\text { Menampilkan halaman informasi penyakit dengan } 3 \text { buah } \\
\text { data penyakit yang berisi } \\
\text { deskripsi, gejala, serta upaya pencegahan dan penanganan. }\end{array}$} \\
\hline Menguji fungsi menu "Back" & $\begin{array}{l}\text { Klik tombol menu } \\
\text { "Back" }\end{array}$ & \multicolumn{2}{|c|}{ Tampil halaman Awal sistem pakar } & Berh \\
\hline \multicolumn{5}{|c|}{ Tabel 6. Pengujian fungsi halaman utama } \\
\hline $\begin{array}{c}\text { Nama } \\
\text { Pengujian }\end{array}$ & \multicolumn{2}{|c|}{$\begin{array}{c}\text { Bentuk } \\
\text { Pengujian }\end{array}$} & Hasil yang Diharapkan & $\begin{array}{c}\text { Hasil } \\
\text { Pengujian }\end{array}$ \\
\hline $\begin{array}{l}\text { Menguji fungsi menu } \\
\text { "Deteksi" }\end{array}$ & \multicolumn{3}{|c|}{$\begin{array}{l}\text { Tekan tombol menu "Mulai Tampil halaman Mulai Deteksi } \\
\text { Deteksi" }\end{array}$} & Berhasil \\
\hline $\begin{array}{l}\text { Menguji fungsi menu } \\
\text { "Informasi Penyakit" }\end{array}$ & \multicolumn{2}{|c|}{$\begin{array}{l}\text { Tekan tombol menu } \\
\text { "Informasi Penyakit" }\end{array}$} & Tampil halaman Informasi Penyakit & Berhasil \\
\hline $\begin{array}{l}\text { Menguji fungsi menu } \\
\text { "Tentang Aplikasi" }\end{array}$ & \multicolumn{3}{|c|}{$\begin{array}{l}\text { Tekan tombol menu "Tentang Tampil halaman Tentang Aplikasi } \\
\text { Aplikasi" }\end{array}$} & Berhasil \\
\hline
\end{tabular}

Tabel 7. Pengujian fungsi halaman deteksi

\begin{tabular}{llll}
\hline \multicolumn{1}{c}{$\begin{array}{c}\text { Nama } \\
\text { Pengujian }\end{array}$} & \multicolumn{1}{c}{$\begin{array}{c}\text { Bentuk } \\
\text { Pengujian }\end{array}$} & Hasil yang Diharapkan & $\begin{array}{c}\text { Hasil } \\
\text { Pengujian }\end{array}$ \\
\hline $\begin{array}{l}\text { Menguji fungsi } \\
\text { masukan "Ya" }\end{array}$ & Tekan tombol masukan "Ya", $\begin{array}{l}\text { Memilih gejala penyakit yang } \\
\text { ditampilkan }\end{array}$ & Berhasil \\
$\begin{array}{l}\text { Menguji fungsi } \\
\text { masukan "Tidak" }\end{array}$ & $\begin{array}{l}\text { Tekan tombol masukan } \\
\text { "Tidak" }\end{array}$ & $\begin{array}{l}\text { Tidak memilih gejala penyakit } \\
\text { yang ditampilkan }\end{array}$ & Berhasil \\
$\begin{array}{l}\text { Menguji fungsi } \\
\text { masukan "Lanjut" }\end{array}$ & $\begin{array}{l}\text { Tekan tombol masukan } \\
\text { "Lanjut" }\end{array}$ & $\begin{array}{l}\text { Menampilkan gejala } \\
\text { selanjutnya }\end{array}$ & Berhasil \\
\hline
\end{tabular}

Tabel 2. Persentase ini kemudian ditampilkan dalam aplikasi.

$$
P(E)=\frac{a}{b} \times 100 \%
$$

\section{Hasil dan Diskusi}

Aplikasi pakar deteksi tuberkulosis ini berjalan di sistem Android. Tampilan awal dan halaman deteksi yang membutuhkan interaksi pengguna ditunjukkan dalam Gambar 4.

Halaman utama aplikasi terdapat 3 menu yaitu menu Mulai Deteksi, menu Informasi Penyakit, dan menu Tentang Aplikasi. Ketika pengguna mengklik menu Mulai Deteksi maka akan diarahkan ke halaman Deteksi. Pada halaman Deteksi berisi pertanyaan gejala dengan jawaban ya atau tidak. Ketika pengguna menekan tombol menu Informasi Penyakit maka diarahkan ke halaman Informasi Penyakit yang berisi data-data penyakit. Halaman Informasi Penyakit berisi informasi dari datadata penyakit yang ditampilkan dalam tab view. Isi dari data penyakit adalah deskripsi dari satu penyakit, gejala, dan upaya pencegahan dan penanganan. Ketika pengguna menekan tombol menu Tentang Aplikasi maka tampilan akan beralih ke halaman Tentang Aplikasi yang berisi penjelasan aplikasi dan data pengembang aplikasi.

Halaman Deteksi berisi pertanyaan gejala dimulai dari gejala umum kemudian mengarah ke gejala khusus. Pengguna memilih gejala dengan menjawab ya atau tidak pada setiap pertanyaan kemudian menekan tombol lanjut. Jika pengguna memilih pertanyaan, akan diarahkan ke gejala lainnya yang berhubungan dengan suatu penyakit yang sesuai sampai menuju pada kesimpulan hasil deteksi dan beralih ke halaman Hasil Deteksi. Gambar 5 dan Gambar 6 menunjukkan kasus pengguna memilih gejala yang dirasakannya dan kesimpulan hasil deteksi yang diberikan oleh aplikasi.

Kasus yang ditunjukkan dalam Gambar 5 dan 6 adalah pengguna aplikasi memilih beberapa pilihan gejala yang dirasakannya yaitu demam, keringat dingin waktu malam hari, lemah letih lesu tidak nafsu makan, batuk berdahak yang berlangsung lebih dari 14 hari, batuk yang mengeluarkan darah, terasa sesak dan nyeri pada dada. Berdasarkan aturan produksi pada Tabel 2 diperoleh penyakit yang memiliki gejala-gejala tersebut yaitu tuberkulosis paru (Gambar 6). Jumlah gejala yang dipilih yang sama dengan gejala tuberkulosis paru adalah 6 dari total 7 gejala dalam penyakit tersebut. Persentase yang ditunjukkan oleh aplikasi terhadap masukan pengguna adalah $85,71 \%$ yang diperoleh dari perhitungan probabilitas klasik sesuai Persamaan 1, yaitu 6/7 x 100\%.

Pengujian sistem menggunakan pengujian fungsional secara black box dan langsung oleh pakar. Pada pengujian oleh pakar dilakukan skenario kasus saat pengguna memilih gejala tertentu yang akan menghasilkan kesimpulan dari penyakit yang diderita. Rencana pengujian fungsional aplikasi sistem pakar deteksi dini tuberkulosis ini dapat dilihat pada Tabel 3. Hasil pengujian fungsional 
halaman utama pada aplikasi sistem pakar ini ditunjukkan oleh Tabel 4. Hasil pengujian halaman deteksi yang dilakukan oleh sistem ini ditunjukkan oleh Tabel 5. Hasil pengujian fungsi halaman hasil deteksi pada aplikasi sistem pakar ditunjukkan oleh Tabel 6. Hasil pengujian fungsi halaman informasi penyakit ditunjukkan dalam Tabel 7. Keseluruhan fungsi sistem pakar telah dapat berjalan dengan baik secara fungsional.

Pengujian pakar pada aplikasi sistem pakar dilakukan untuk memvalidasi hasil diagnosis. Pengujian pakar dilakukan secara objektif di mana aplikasi diuji secara langsung. Pengujian pakar dilakukan oleh dr. Fathur Nur Kholis, Sp.PD. dari bagian S.M.F. Penyakit Dalam, RSUP Dr. Kariadi Semarang. Hasil pengujian oleh pakar ditunjukkan pada Gambar 7. Hasil pengujian ini dibandingkan dengan hasil pada Gambar 5 dan Gambar 6 untuk memberikan diagnosis terhadap penyakit tuberkulosis paru dengan gejala demam, keringat dingin waktu malam hari, lemah letih lesu tidak nafsu makan, batuk berdahak yang berlangsung lebih dari 14 hari, batuk yang mengeluarkan darah, terasa sesak dan nyeri pada dada. Pakar membenarkan diagnosis sistem pakar sesuai dengan gejala-gejala yang timbul dalam kasus pengujian.

Sistem pakar telah ini dapat berfungsi untuk mendeteksi dini tuberkulosis seperti halnya [7]-[11], khususnya tuberkulosis paru, tuberkulosis tulang, dan tuberkulosis kelenjar. Namun, sistem ini telah berjalan di perangkat Android, seperti halnya [4]-[5], sehingga dapat dijalankan secara mobile dan memudahkan pengguna untuk menggunakannya. Metode forward chaining yang digunakan dalam aplikasi telah divalidasi oleh seorang pakar [9], [11]. Tidak seperti penggunaan probabilitas klasik untuk menghitung persentase gejala yang dipilih untuk suatu penyakit, penggunaan CF seperti dalam [7], [10] atau metode Dempster Shafer, seperti dalam [12]. dapat diterapkan untuk mendeteksi tuberkulosis paru, tulang, dan kelenjar sehingga memberikan jangkauan keyakinan pengguna dalam memberikan informasi gejala yang dirasakannya.

\section{Kesimpulan}

Sistem pakar pendeteksi penyakit tuberkulosis berbasis Android dengan menggunakan metode forward chaining telah berhasil dikembangkan. Sistem pakar ini telah dapat memberikan deteksi dini penyakit tuberkulosis paru, tuberkulosis tulang, dan tuberkulosis kelenjar berdasarkan 18 gejala yang menyertai ketiga penyakit tersebut. Persentase gejala yang dirasakan pengguna terhadap total gejala yang mungkin untuk suatu penyakit telah dapat disajikan dengan probabilitas klasik. Validasi oleh satu orang pakar telah memberikan hasil sesuai dengan yang diharapkan. Validasi oleh lebih dari satu pakar masih harus dilakukan untuk memberikan tingkat akurasi deteksi yang lebih baik.

\section{Persantunan}

Terima kasih diucapkan kepada dr. Fathur Nur Kholis, Sp. PD. yang telah membantu dalam menyelesaikan penelitian ini dan berperan sebagai pakar.

\section{Daftar Pustaka}

[1] A.G. Icksan, and R. Luhur,S. Iwan, "Radiologi Toraks Tuberkulosis Paru ," CV. Agung Seto, Jakarta, 2008.

[2] D. Sarwani, S. Nurlaela, and Z. A. Isnani, "Risk Factors of Multidrug Resistant Tuberculosis (MDR-TB)," Jurnal Kesehatan Masyarakat, vol. 8, no. 1, pp. 60-66, 2012.

[3] R. A. Werdhani, "Patofisiologi, Diagnosis, dan Klafisikasi Tuberkulosis," Departemen Ilmu Kedokteran Komunitas, Okupasi, dan Keluarga FKUI, 2002.

[4] M.P. Hardiyanti, R. R. Isnanto, and I. P. Windasari, "Aplikasi Sistem Pakar Berbasis Mobile untuk Diagnosis Dini Meningitis," Jurnal Teknologi dan Sistem Komputer, [Online] vol. 5(2), pp. 83-88, doi:10.14710/jtsiskom.5.2.2017.84-89, 2017

[5] M. P. N. Saputri, R. R. Isnanto, and I. P. Windasari,. Aplikasi Sistem Pakar Pendeteksi Gastroenteritis Berbasis Android. Jurnal Teknologi dan Sistem Komputer, [Online] vol. 5(3), pp. 110-114, doi:10.14710/jtsiskom.5.3.2017.110-11, 2017.

[6] B. A. Herlambang, and V. A. V. Setyawati, "Perancangan Data Flow Diagram Sistem Pakar Penentuan Kebutuhan Gizi Bagi Individu Normal Berbasis Web," Jurnal Informatika Upgris, vol. 1(1), 2015.

[7] Y. P. Bria, and E. A. S. Takung, "Pengembangan Sistem Pakar Diagnosis Penyakit Tuberculosis dan Demam Berdarah Berbasis WEB Menggunakan Metode Certainty Factor," Prosiding Seminar Nasional Teknologi Informasi dan Komunikasi, pp. 271-276, 2015.

[8] N. Aini, R. Ramadiani, and H.R. Hatta, "Sistem Pakar Pendiagnosa Penyakit Tuberkulosis," Informatika Mulawarman, vol. 12(1), pp.56-63, 2017.

[9] M. Arsyad, "Implementasi Metode Sugeno Pada Sistem Pakar Penentuan Stadium Pada Penyakit Tuberculosis (TBC)," Pelita Informatika Budi Darma, vol. 7(3), pp. 22-27, 2014.

[10] W. Widiastuti, D.D.S. Fatimah, and D.J. Damiri, "Aplikasi Sistem Pakar Deteksi Dini Pada Penyakit Tuberkulosis,” Jurnal Algoritma, vol. 9(01), 2012.

[11] E.D.S. Mulyani, and I.N. Restianie, "Aplikasi Sistem Pakar untuk Mendiagnosa Penyakit Anak (Balita) dengan Menggunakan Metode Forward Chaining," SEMNASTEKNOMEDIA ONLINE, 4(1), pp. 43-47, 2016.

[12] E. Lestari, and E. U. Artha, "Sistem Pakar dengan Metode Dempster Shafer untuk Diagnosis Gangguan Layanan Indihome di PT Telkom Magelang," Khazanah Informatika, vol. 3(1), pp. 16-24, 2017. 


\section{Mitra Bestari (Reviewer)}

Dewan editor mengucapkan terima kasih yang sebesar-besarnya atas partisipasi para reviewer berikut ini yang telah membantu dalam proses penerbitan jurnal Khazanah Informatika volume 4 tahun 2018.

1. Jan Wantoro, UMS

2. Dr. Endah Sudarmilah, UMS

3. Tati Ernawati, Politeknik TEDC Bandung

4. Adi Supriyatna, AMIK BSI Karawang

5. Sitaresmi Wahyu Handani, AMIKOM Purwokerto

6. Dwi Ely Kurniawan, Politeknik Negeri Batam

7. Yusuf Sulistyo Nugroho, UMS

8. Dedi Gunawan, UMS

9. Endang Wahyu Pamungkas, UMS

10. Umi Fadlilah, UMS

11. Yogiek Indra Kurniawan, UMS

12. Dr. Bana Handaga, UMS

13. Dr. Heru Supriyono, UMS

14. Sukirman, UMS 